\title{
Autoimunitní hepatitida
}

\section{Petr Urbánek}

Interní klinika 1. LF UK a ÚVN Praha

Autoimunitní hepatitida je chronické zánětlivé onemocnění jaterní tkáně z neznámé př́činy, které je charakteristické sérologickou reaktivitou různých typů autoprotilátek a hypergamaglobulinemií. Postiženými jsou převážně ženy mladšího či středního věku. Bez léčby dochází ve většině případů k postupné progresi onemocnění a k rozvoji jaterní cirhózy se všemi důsledky. Klinická manifestace není jednotná, existuje několik fenotypů manifestace: akutní jaterní hepatocelulární poškození připomínající akutní virovou hepatitidu, vzácnější je manifestace ve formě fulminantní hepatitidy, nejčastěji však má onemocnění pliživý průběh, kdy jedinou možnou známkou jaterního onemocnění je dlouhodobý mírný vzestup sérových aktivit jaterních transamináz. V klinicky méně vyjádřených prípadech může být rozpoznání onemocnění diagnostickým problémem. $V$ těchto prípadech Ize použít několik skórovacích systémů, které jsou účinným diagnostickým pomocníkem. Terapeutickým cílem je dosažení kompletní odpovědi, která je definována jako úplná normalizace sérové aktivity ALT i AST a normalizace sérové koncentrace gamaglobulinů. Léčba se dělí do dvou fází: indukční a udržovací. Základním postupem obou fází je podání prednisonu v monoterapii či v kombinaci s azatioprinem. Při vysazení léčby jsou relapsy velmi časté, během 3 let relabuje až $80 \%$ nemocných.

Klíčová slova: autoimunitní hepatitida, imunosupresivní terapie, jaterní cirhóza.

\section{Autoimmune hepatitis}

Autoimmune hepatitis is a chronic inflammatory disease of hepatic tissue of unknown aetiology characterized by serological reactivity of various types of autoantibodies and hypergammaglobulinaemia. It predominantly affects younger or middle-aged women. If untreated, in the majority of cases there occurs gradual disease progression and development of liver cirrhosis with all its consequences. Clinical manifestations are not uniform, with several manifestation phenotypes having been identified: acute hepatocellular injury resembling acute viral hepatitis; more rarely, a manifestation in the form of fulminant hepatitis; most commonly, however, the disease has a silent clinical course, with a chronic mild elevation in serum hepatic transaminase activity being the only possible sign of liver disease. In clinically less obvious cases, recognition of the disease may be a diagnostic challenge. In these cases, several scoring systems can be used that effectively aid in diagnosing the condition. The therapeutic goal is to achieve a complete response defined as full normalization of the serum ALT and AST activities, as well as normalization of serum gamma globulin concentration. The treatment is divided into two phases: induction and maintenance. The administration of prednisone in monotherapy or in combination with azathioprine is the basic procedure in both phases. Relapses are very frequent when treatment is discontinued, with as many as $80 \%$ of the patients having a relapse within three years. Key words: autoimmune hepatitis, immunosuppressive therapy, liver cirrhosis.

\section{Úvod}

Autoimunitní hepatitida (AlH) je chronické zánětlivé onemocnění jaterní tkáně vznikající z neznámé př́činy. Charakteristickými rysy onemocnění je vysoká aktivita sérových transamináz (ALT, AST), vysoká sérová koncentrace gamaglobulinů (lgG) a v typickém př́padě i pozitivita sérových autoprotilátek. V histologickém obraze je typickým nálezem tzv. „interface“ hepatitida (1).

Onemocnění jako první popsal v roce 1950 Waldenström, který si všiml u mladých žen asociace jaterního onemocnění vedoucího v průběhu času k jaterní cirhóze s významnou hypergamaglobulinemií (2). 
V minulosti se pro AlH používaly nejrůznější názvy. V roce 1956 Mackay poprvé použil termín lupoidní hepatitida, ale až s objevem LE buněk a antinukleárních protilátek byl postupně stejným autorem v roce 1965 zaveden termín autoimunitní hepatitida $(3,4)$. S technologickým pokrokem 70. let minulého století se podařlo kromě antinukleárních protilátek identifikovat i další typy autoprotilátek (nejdřive LKM-1, později anti-SLA - viz dále) a AlH se tak rozdělila na 3 základní typy. Po objevu HCV a možnostech detekce anti-HCV protilátek se ještě v rámci AlH II. typu rozlišoval typ Ila s reaktivními anti-HCV protilátkami a typ Ilb bez reaktivity anti-HCV. Toto dělení typu II však bylo opět vzápětí velmi rychle opuštěno poté, co se jednoznačně prokázalo, že jde o tzv. sekundární autoimunitní fenomén u chronické HCV infekce. AlH byla prvním jaterním onemocněním, u kterého byly podány důkazy o tom, že farmakoterapie vede $\mathrm{k}$ prodloužení přežití. První studii v tomto smyslu publikoval v roce 1980 Kirk et al (5). Autoři prokázali významné prodloužení přežití u osob s pozitivním průkazem antinukleárního faktoru léčených prednisolonem (poznámka autora: prednison je proléčivo, které je v játrech transformováno na účinný metabolit prednisolon. V ČR nemá prednisolon ve formě pro perorální užití stanovenu úhradu, což je rozdí proti většině zemí EU. Většina v prehledu citované literatury proto zmiňuje prednisolon, ale v ČR Ize ve stejných situacích použit perorální prípravky obsahujicí prednison) v dávce $15 \mathrm{mg}$ až do normalizace ALT proti skupině osob, které léčeny prednisolonem nebyly. V léčené skupině bylo 10 leté přežití téměř $70 \%$, ve skupině neléčené pouze $30 \%$.

\section{Klinický obraz}

AlH nemá jednotnou klinickou prezentaci, což přirozeně významně komplikuje její rozpoznání, stanovení diagnózy i optimální péči $(6,7)$. Onemocnění postihuje obě pohlaví, dominantně nicméně ženy (přibližně 4: 1), vyskytuje ve všech věkových skupinách a ve všech rasách a etnických skupinách (8). Pacienti se mohou manifestovat obrazem akutního jaterního poškození připomínajícím akutní virovou hepatitidu, extrémním prípadem může být těžký akutní (fulminantní) obraz (7). Stejně tak ale může být klinický obraz pliživý až asymptomatický. Pacienti nemusí mít vyjádřeny typické sérologické známky, mohou mít i atypický histologický obraz onemocnění. Na AlH je třeba myslet ve všech prípadech akutní i chronické hepatitidy nemající jinou jasnou príčinu, včetně pacientůs dysfunkcí štěpu po transplantaci jater (9).

\section{Varianty klinické manifestace}

\section{Akutní a těžká akutní (fulminantní) hepatitida}

Akutní manifestace je popisována 25-75\% pacientů s AlH, fulminantní hepatitida s obrazem akutního jaterního selhání se vyskytuje v Evropě a Severní Americe u 3-6\% případů AlH (10). Obě varianty připomínají akutní virovou nebo toxickou akutní jaterní lézi. V diferenciální diagnóze je třeba uvažovat i o polékovém jaterním poškození (DILI). Situace je o to složitější, že v prípadech akutní manifestace velmi často chybějí typické znaky AlH: antinukleární protilátky (ANA) Ize prokázat u méně než 1/3 pacientů, IgG mají normální sérovou koncentraci až u 40\% prípadů. Typickým histologickým nálezem (> 85\%) je centrilobulární hemoragická nekróza jater nebo rưzně rozsáhlá nekróza tkáně (11).
Dalšími nálezy svědčícími pro diagnózu AlH je centrální perivenulitida s lymfoplazmocytárním infiltrátem a interface hepatitidou (12).

\section{Asymptomatický průběh}

AlH je asymptomatická u 25-35\% pacientů. Na diagnózu AlH je proto třeba myslet u všech osob s nově prokázanou mírnou elevací sérových aktivit jaterních transamináz ALT a AST (13). Od prvního zjištění elevace transamináz do rozvoje jaterní symptomatologie může u osob bez správné diagnózy uběhnout 2-120 měsíců. Symptomatologie v těchto prípadech zahrnuje únavu, bolesti a tlaky v pravém podžebří, nechutenství, pruritus, polyartralgii malých kloubů (velmi často roky trvající a vedoucí k špatné diagnóze či dokonce k intermitentnímu podávání kortikoterapie). Histologické nálezy u těchto prípadů zahrnují především různě těžkou interface hepatitidu (85-93\%), periportální či přemostujující fibrózu (40-50\%) (13). Jaterní cirhóza je v těchto prípadech popisována až v 1/3 prípadů, což predpokládá léta trvající pomalý, skrytý průběh onemocnění. Spontánní remise onemocnění je vzácná, dochází k ní vzácněji, než lze dosáhnout kompletní remise indukční terapií u těžké fulminantní hepatitidy během sledovacího období $77 \pm 31$ měsíců ( $12 \%$ vs. $63 \%, p=0,006)$. Neléčené osoby mají také nižší 10 leté přežití (67\% vs. $98 \%, p=0,01)$ (14). I u pacientů se středně aktivním onemocněním je proto indikace k imunosupresivní terapii.

\section{Séronegativní manifestace}

Jako séronegativní se označují osoby s negativním sérologickým průkazem typických autoprotilátek (viz dále) (15). U těchto prípadů je velmi vhodným nástrojem pomáhajícím stanovení správné diagnózy revidovaný skórovací systém IAlHG (viz dále). Při užití tohoto systému bylo v evropské populaci reklasifikováno jako AlH až 34\% osob, které byly do té doby vedeny jako kryptogenní chronická hepatitida (16). ANA nebo protilátky proti hladkému svalu (SMA) se mohou objevit později $\checkmark$ průběhu onemocnění, je potřeba proto jejich stanovení opakovat. U séronegativní manifestace se lze setkat s pozitivitou protilátek ze skupiny netypických tak, jak je o nich zmínka dále. Jedná se zejména o protilátky proti rozpustnému jaternímu antigenu (10-30\%) (17). Objevit se můžou i atypické perinukleární protilátky proti cytoplazmě neutrofilních leukocytů, diagnózou může podpořit i průkaz protilátek proti tkáňové transglutamináze v rámci celiakie (18). Je třeba zdůraznit, že séronegativita nevylučuje diagnózu AlH ani prínos imunosupresivní terapie ve smyslu potlačení zánětlivé aktivity biochemické i histologické (19).

\section{Atypická histologická manifestace}

Interface hepatitida je považována za podmínku sine qua non pro diagnózu AlH, ale kromě toho existuje rozsáhlé spektrum dalších histologických nálezů, které mohou interface hepatitidu doprovázet (9). Nekróza centrilobulární zóny 3 jaterního lalůčku se vyskytuje asi u 1/3 případů a může při terapii vymizet (20). Výše zmíněná centrilobulární nekróza může být znakem akutní až fulminantní hepatitidy, ale stejně tak bývá popisována u spontánní exacerbace chronicky mírně probíhajícího onemocnění (21). Pacienti s centrilobulární nekrózou dobře odpovídají na imunosupresivní léčbu a pravděpodobně dosahují biochemické remise častěji než osoby bez nekrózy (95\% vs. 88 \%) (20). Dalším nálezem 
doprovázejícím interface hepatitidu může být poškození žlučových cest (22). Izolované postižení malých žlučovodů bez klinického syndromu cholestázy při negativitě antimitochondriálních protilátek (AMA) může však být rysem AMA negativní primární biliární cholangoitidy (PBC) (23). Destruktivní cholangoitida ve spojení s AMA, ale i dalšími rysy AlH jsou podkladem překryvného syndromu AlH/PBC (24). Duktopenie, portální fibróza a portální edém jsou zase typickým nálezem překryvného syndromu AlH a primární sklerotizující cholangoitidy (AIH/PSC) (25).

\section{Překryvné syndromy}

Dvě základní varianty překryvného syndromu byly zmíněny v předchozím odstavci, AlH/PBC a AlH/PSC. Pacienti s AlH však mohou mít i cholestatický syndrom při absenci znaků PBC i PSC. U těchto osob může jít o překryv AlH s AMA negativní PBC nebo tzv. PSC s postižením malých vývodů (small duct PSC) (24, 26). Překryvné syndromy jsou popisovány u asi $10 \%$ pacientů s AlH (24). Nejdůležitějším důsledkem existence překryvných syndromů je variabilní odpověd' na imunosupresivní terapii. U pacientů s cholestázou je doporučována kombinace imunosupresivní léčby s ursodeoxycholovou kyselinou (27). Za „zlatý standard" při snaze o diagnózu prekryvných syndromů je považován expertní názor a histologické vyšetření (28).

\section{Diagnóza}

Jedním z typických znaků AlH je pozitivní průkaz několika typů autoprotilátek. Jedná se o autoprotilátky většinou orgánově nespecifické, které se často vyskytuji i u jiných onemocnění, než je AlH. Jejich pozitivní průkaz přitom není nezbytnou podmínkou stanovení diagnózy AlH. Senzitivita a specificita jejich průkazu je proto u jednotlivých typů velmi rozdílná a s touto limitací je proto třeba počitat zejména u nejednoznačně vyjádřených případů. Základní metodikou stanovení jejich prítomnosti v séru vyšetřované osoby je neprímá imunofluorescence. U většiny autoprotilátek je však dnes již známa cílová struktura a její primární struktura, takže jsou často dostupné i metody ELISA a odvozené techniky. Obecně však platí, že detekce autoprotilátek (zejména atypických, viz dále) není ani technicky jednoduchá, ani standardizovaná, ani levná, a proto nemusí být celé jejich spektrum běžně dostupné

\section{Sérologické markery}

\section{Standardní autoprotilátky}

Do skupiny tzv. standardních autoprotilátek raadíme antinukleární protilátky (ANA), protilátky proti hladkému svalu (SMA) a protilátky proti jaterním a ledvinným mikrozomům typu 1 (LKM-1). Tyto protilátky charakterizují většinu prípadů AlH. Jejich vyšetření by proto mělo být standardní součástí vyšetření osoby se suspekcí na AlH. ANA a SMA jsou obvykle prokazatelné při absenci LKM-1 a obráceně, což umožnilo odlišení dvou typů AlH, AlH-1 a AlH-2 (29). Oba typy se klinicky liší věkovým složením postižených osob, genetickou predispozicí, ale nikoliv efektem imunosupresivní terapie (30, 31). Rozdělení AlH na tyto dva typy je v posledních letech opakovaně zpochybňováno, protože se nikdy nepodařilo prokázat významné laboratorní, histologické či genetické rozdíly, které by dělení odůvodnily (32).

\section{Antinukleární protilátky a protilátky proti hladkému svalu}

Antinukleární protilátky (ANA) a protilátky proti hladkému svalu (SMA) postrádají specificitu jak ve smyslu onemocnění, tak ve smyslu postižení orgánů. ANA Ize prokázat až u 80\% prípadů AlH, SMA u 63\% prípadů AlH (33). ANA Ize prokázat u 20-40\% alkoholické choroby jater, u NAFLD, ale i u primární biliární cholangoitidy (PBC) či primární sklerotizující cholangoitidy (PSC) (33). SMA Ize u stejných onemocnění prokázat ve 3-16\% případů. Pokud je jejich reaktivita prokazována izolovaně, je senzitivita ANA 32\% a SMA 16\% pro diagnózu AlH. Pokud je prokázána současná reaktivita ANA i SMA, je senzitivita $43 \%$ a specificita až 99\% (33). ANA jsou považovány za nejvariabilnější marker v průběhu onemocnění (17). ANA jsou reaktivní proti mnoha jaderným komponentám, např. proti centromerám, ribonukleoproteinům, histonům, ribonukleoproteinům. 46\% osob s ANA má reaktivitu vůči více než jediné komponentně (34). SMA jsou namíreny především proti vláknitému aktinu, pouze u 14\% osob je popisována aktivita proti jiným strukturám než proti aktinu (34).

\section{Protilátky proti jaterním a ledvinným mikrozomům 1}

Protilátky proti jaterním a ledvinným mikrozomům 1 (LKM-1) jsou prokazatelné u $3 \%$ prípadů AlH v USA, u 14-38 \% prípadů v Evropě (35). Lze je prokázat až u 10 \% nemocných s chronickou HCV infekcí (32). Jejich cílovým epitopem je cytochrom monooxygenáza P450 2D6 (36). Jejich specificita je $99 \%$, pouze $2 \%$ osob s ANA či SMA pozitivitou mají pozitivitu také LKM-1.

\section{Nestandardní autoprotilátky}

Nestandardní autoprotilátky představují skupinu sérologických markerů, které mohou podpořit diagnózu AlH u pacientů, u kterých standardní protilátky nejsou suficientní pro stanovení diagnózy $(37,38)$.

\section{Protilátky proti aktinu}

Protilátky proti aktinu jsou zamířeny proti vláknitému (F) aktinu a jsou prokazatelné až u $87 \%$ pacientů s AlH $(37,39)$. Tyto protilátky jsou prokazatelné i u řady jiných nejaterních autoimunitních onemocnění, jako je systémový lupus, Sjögrenův syndrom, revmatoidní artritida, celiakie, diabetes, autoimunitní tyreoiditida a Crohnova nemoc (37). Protilátky proti aktinu jsou podskupinou SMA, 85-100\% SMA pozitivních osob s AlH mají tuto podskupin reaktivní (40). SMA i antiaktin protilátky jsou nepř́mými markery laboratorní i histologické aktivity onemocnění (41). Většina antiaktin pozitivních osob má pozitivní SMA, ANA nebo LKM-1 protilátky (39). Někteří autoři prokazují vyšší jaterní mortalitu u osob s pozitivními protilátkami proti aktinu, avšak tyto korelace jsou závislé na použitém detekčním kitu $(42,47)$.

\section{Protilátky proti a-aktininu}

a-aktininy jsou proteiny, které se vážou na aktin. Existují ve 2 izoformách: $\checkmark$ buňkách svalových a ostatních (44). Protilátky proti a-aktininu byly prokázána metodou ELISA u 42\% pacientů s AlH ve srovnání s 13\% pacientů s jinými jaterními nemocemi. Prokazatelné jsou ale i u 6\% zdravých jedinců. Tyto protilátky jsou prokazatelné až u 2/3 pacientů s AlH s pozitivními protilátkami proti $F$ aktinu a kombinace obou typư je pravděpodobně specifická pro AlH (45). Dvojitá reaktivita anti-F aktin a anti-a-aktinin má 
ž̌ejmě prognostický význam. Pacienti s oběma typy protilátek mají vysoce aktivní onemocnění charakterizované akutním začátkem (45). Pacienti, kteři odpovídají na léčbu kortikosteroidy, mají nižší vstupní titry anti-a-aktininu než osoby, které relabují nebo mají inkompletní odpověd' na léčbu. Detekce anti-a-aktininu však není jednoduše dostupná.

\section{Protilátky proti rozpustnému jaternímu antigenu}

Protilátky proti rozpustnému jaternímu antigenu (anti-SLA) jsou prokazatelné u 7-22\% pacientů s AlH, jejich výskyt je vysoce rozdílný u různých etnických skupin, nejvzácněji se vyskytují v Japonsku (46). Rozdíly výskytu souvisí pravděpodobně s výskyty různých HLA haplotypů. Jejích pozitivita je asociována s HLA DRB*0301 a HLA A1-B8 (47). Anti-SLA jsou vysoce specifické pro AlH (99\%) a mohou být jediným pozitivním sérologickým markerem až u 20\% pacientů s AlH klasifikovanými mylně jako kryptogenní chronická hepatitida (48). Jejich pozitivita je také asociována se závažnějším histologickým nálezem, delším trváním terapie do dosažení remise, vyšší frekvencí relapsů po skončení léčby a vyšší frekvencí transplantace jater a vyšší pravděpodobností úmrtí z jaterních príčin (49). Cílovou strukturou těchto protilátek je t-RNA protein komplex, recentně označený jako SEPSECS (Sep (O-fosfoserin) tRNA:Sec (selenocystein) tRNA syntáza) $(50,51)$.

\section{Atypické perinukleární protilátky proti cytoplazmě neutrofilních leukocytů}

Atypické perinukleární protilátky proti cytoplazmě neutrofilních leukocytů (pANCA) jsou prokazatelné u 50-92\% pacientů s AlH (52). Titry PANCA pritom nekorelují s aktivitou onemocnění. Nevyskytují se nikdy spolu s LKM-1, prokazatelné jsou naopak u jiných onemocnění (PSC, PBC, ulcerózní kolitida) (53). Cílovým epitopem je protein o hmotnosti 50 kDa vyskytující se na vnitřní straně obalu jádra označovaný jako ß-tubulin izotyp 5 (52). pANCA byly začleněny do výše zmíněných klasifikačních systémů a jejich průkaz může být opět jediným sérologickým markerem AlH u osob do té doby mylně klasifikovaných jako kryptogenní chronická hepatitida. Pozitivita pANCA je asociována s jaterní cirhózou a relapsy po ukončení terapie kortikosteroidy (54). Prognostický význam pANCA u AlH však dosud nebyl dostatečně datově podpořen, a proto k těmto účelům nelze tyto protilátky použít.

\section{Protilátky proti asialoglykoproteinovému receptoru}

Protilátky proti asialoglykoproteinovému receptoru (anti-ASPGR) jsou prokazatelné u 67-88\% pacientů s AlH (52). Vyskytují se i u akutní hepatitidy A či B, u alkoholické jaterní choroby, u chronické hepatitidy B (53). Tato jejich nízká specificita je základní limitací jejich použití. Na druhou stranu mohou být opět jediným pozitivním sérologickým markerem u osob s negativitou všech ostatních sérologických markerů AlH (55). Anti-ASPGR mohou vymizet při imunosupresivní terapii a jejich vymizení koreluje s vymizením histologické aktivity (58). Osoby, u nichž anti-ASPGR přetrvávají i během imunosupresivní léčby, mají vyšší riziko relapsu onemocnění po ukončení léčby než osoby, u kterých anti-ASPGR během léčby vymizí (58). Nevýhodou a limitací použití anti-ASPGR jako klíčového vyšetření pro terapeutická rozhodování je jejich obtižná a nestandardizovaná detekce, v rutinní praxi je k tomuto účelu nelze použít (59).

\section{Protilátky proti jaternímu cytozolu typu 1}

Protilátky proti jaternímu cytozolu typu 1 (anti-LC1) byly prvně popsány v roce 1988 a jsou prokazatelné u 24-32 \% pacientů s LKM1 pozitivitou (60). Odlišení imunoflurescence obou typů protilátek v jaterní tkáni bývá proto diagnostickým problémem. Typicky se jejich pozitivita objevuje u evropských pacientů mladších 20 let (61). Anti-LC1 mohou být jediným sérologickým markerem u osob séronegativních pro všechny ostatní markery (62). U dětí jde až o $10 \%$ séronegativních prípadi̊. Jejich cílovou strukturou je cytozolový enzym formiminotransferáza-cyklodeamináza (63). Autoprotilátky tohoto typu jsou považovány za relativně specifický nález u LKM-1 pozitivní AlH, vyskytnout se mohou vzácně u SMA pozitivní AlH a u chronické HCV infekce (64).

Jak bylo zmíněno, stanovení diagnózy AlH je jednoduché v typických prípadech. Naopak u méně vyjádřených klinických prípadů jde většinou o složitý problém. Diagnostická kritéria pro jistou a pravděpodobnou diagnózu AlH podle IAIHG z roku 1999 ukazuje tab. 1. Označení "jistá" a „pravděpodobná" AlH definuje míru spolehlivosti stanovení diagnózy AlH podle míry shody vyjmenovaných parametrů. Diagnóza může být jednoduchá v typických a plně vyjádřených případech: chronická/akutní jaterní léze u mladé ženy doprovázená

Tab. 1. Diagnostická kritéria pro AlH podle IAIHG 1999

\begin{tabular}{|c|c|}
\hline Jistá AlH & Pravděpodobná AlH \\
\hline Normální a1-antitrypsin fenotyp & Parciální a1-antitrypsin deficience \\
\hline Normální sérová koncentrace ceruloplazminu & Nediagnostická koncentrace ceruloplazminu \\
\hline Absence aktivní virové infekce HAV, HBV, HCV & Absence aktivní virové infekce HAV, HBV, HCV \\
\hline Denní príijem alkoholu < $25 \mathrm{~g}$ & Denní príijem alkoholu < $50 \mathrm{~g}$ \\
\hline Absence recentního podání hepatotoxických léčiv & Absence recentního podání hepatotoxických léčiv \\
\hline Dominantní AST/ALT elevace & Dominantní AST/ALT elevace \\
\hline gamaglobuliny nebo lgG koncentrace > 1,5krát horní limit normy & Hypergamaglobulinemie jakéhokoliv stupně \\
\hline ANA, SMA, Anti-LKM-1 > 1:80 u dospělých a > 1:20 u dětí & ANA, SMA, Anti-LKM-1 > 1:40 u dospělých \\
\hline Negativní AMA & Další autoprotilátky \\
\hline Jaterní histologie & Jaterní histologie \\
\hline $\begin{array}{l}\text { Střední až těžká interface hepatitida } \\
\text { Absence postižení žlučovodů, granulomů a dalších změn obvyklých u jiných } \\
\text { onemocnění }\end{array}$ & $\begin{array}{l}\text { Střední až těžká interface hepatitida } \\
\text { Absence postižení žlučovodů, granulomů a dalších změn obvyklých u jiných } \\
\text { onemocnění }\end{array}$ \\
\hline
\end{tabular}


Tab. 2. Kompletní diagnostický skórovací systém AlH podle IAlHG z roku 1999

\begin{tabular}{|c|c|c|c|}
\hline Parametr & Počet bodů & Parametr & \multirow[t]{2}{*}{ Počet bodů } \\
\hline Ženské pohlaví & +2 & Průměrný příjem alkoholu (g/den) & \\
\hline$A L P: A S T$ (nebo ALP:ALT) & & \begin{tabular}{l|l|} 
& $<25$ \\
\end{tabular} & +2 \\
\hline \begin{tabular}{l|l|} 
& $<1,5$ \\
\end{tabular} & +2 & \begin{tabular}{l|l|} 
& $>60$ \\
\end{tabular} & -2 \\
\hline $1,5-1,0$ & 0 & Histologický nález & \\
\hline$>3,0$ & -2 & \begin{tabular}{|l|l|} 
Interface hepatitida \\
\end{tabular} & +3 \\
\hline $\begin{array}{l}\text { Sérová koncentrace globulinů nebo lgG } \\
\text { (násobky horního limitu normy) }\end{array}$ & & Lymfoplazmocytární infiltrace & +1 \\
\hline $\mid>2,0$ & +3 & Tvorba rozet & +1 \\
\hline $1,5-2,0$ & +2 & Změny žlučovodů & -3 \\
\hline $1,0-1,5$ & +1 & Další atypické změny & -3 \\
\hline$<1,0$ & 0 & Žádné z výše uvedených & -5 \\
\hline$A N A, S M A, L K M-1$ & & Současnéjiné autoimunitní onemocnění včetně celiakie & +2 \\
\hline \begin{tabular}{l|l} 
& $>1: 80$ \\
\end{tabular} & +3 & Jiné autoprotilátky & +2 \\
\hline $1: 80$ & +2 & HLA DRB1*03 nebo DRB1*04 & +1 \\
\hline $1: 40$ & +1 & Odpověd'na kortikoidy & \\
\hline$<1: 40$ & 0 & \begin{tabular}{|l|l|} 
& Kompletní \\
\end{tabular} & +2 \\
\hline AMA pozitivní & -4 & Relaps po vysazení & +3 \\
\hline \multicolumn{4}{|l|}{ Sérologie virových hepatitid } \\
\hline \begin{tabular}{l|l} 
Pozitivní \\
\end{tabular} & -3 & & \\
\hline \begin{tabular}{l|l|} 
& Negativní \\
\end{tabular} & +3 & Agregované skóre před léčbou & \\
\hline Expozice hepatotoxickým lékům & & \begin{tabular}{|l|l|} 
& Jistá AlH \\
\end{tabular} & $>15$ \\
\hline \begin{tabular}{l|l} 
Pozitivní \\
\end{tabular} & -4 & \begin{tabular}{l|l|} 
& Pravděpodobná AlH \\
\end{tabular} & $10-15$ \\
\hline Negativní & +1 & Agregované skóre po léčbě & \\
\hline & & \begin{tabular}{|l|l|} 
& Jistá AlH \\
\end{tabular} & $>17$ \\
\hline & & Pravděpodobná AlH & $12-17$ \\
\hline
\end{tabular}

hypergamaglobulinemií, pozitivním průkazem některých autoprotilátek a při vyloučení akutní hepatitidy virové etiologie. V netypických případech nebo prípadech s vyjádřením pouze některých klinických či laboratorních rysů se však neobejdeme bez použití skórovacích systémů. K tomuto účelu určení diagnózy v nejednoznačných prípadech byly sestaveny 2 systémy:

- První systém vytvořila International Autoimmune Hepatitis Group v roce 1999 (65) (tab. 2). Systém byl původně vytvořen za účelem maximální standardizace vstupních kritérií pro klinické studie s AlH, postupně se nicméně stal důležitým diagnostickým vodítkem. Jeho výhodou je, že Ize použít jak pred zahájením terapie kortikosteroidy, tak i po jejich podání.
Tab. 3. Zjednodušený diagnostický skórovací systém AlH

\begin{tabular}{|l|l|l|}
\hline Parametr & Diskriminátor & Skóre \\
\hline ANA nebo SMA+ & $\geq 1: 40$ & +1 \\
\hline ANA nebo SMA+ & $\geq 1: 80$ & +2 \\
\hline nebo LKM+ & $\geq 1: 40$ & +2 \\
\hline nebo SLA/LP+ & Jakýkoliv titr & +2 \\
\hline Hladina IgG nebo & $>$ ULN & +1 \\
gamaglobulinů & $>1,1$ krát ULN & +2 \\
\hline Jaterní histologie & Kompatibilní S AlH & +1 \\
Aktivní „interface" & Typická AlH & +2 \\
hepatitida & Atypický nález & 0 \\
\hline Absence virové infekce & Ne & 0 \\
& Ano & +2 \\
\hline
\end{tabular}

Pravděpodobná diagnóza $A l H \geq 6$ bodů, jistá diagnóza $\geq 7$ bodů

Tab. 4. Tradiční klasifikace a charakteristika jednotlivých typů AlH

\begin{tabular}{|c|c|c|}
\hline Subtyp AlH & Typické rysy & Klinická charakteristika \\
\hline AlH-1 & $\begin{array}{l}\text { - Pozitivní detekce ANA, SMA nebo anti-SLA } \\
\text { - Asociace s HLA DR3, DR4 a DR13 }\end{array}$ & $\begin{array}{l}\text { - asi } 90 \% \text { všech př́ípadů AlH } \\
\text { - začátek v kterémkoliv věku } \\
\text { - většinou dobrá odpověd' na imunosupresivní léčbu, avšak časté relapsy při vysazení, proto } \\
\text { vyžaduje většinou dlouhodobou udržovací léčbu }\end{array}$ \\
\hline $\mathrm{AlH}-2$ & $\begin{array}{l}\text { - Anti-LKM1, anti-LC1 a vzácně anti-LKM3 } \\
\text { - Asociace s HLA DR3 a DR7 }\end{array}$ & $\begin{array}{l}\text { - výskyt do } 10 \text { \% prí́padů AlH } \\
\text { - začátek většinou v dětství nebo v mladším dospělém věku } \\
\text { - klinicky i histologicky často vysoká aktivita a pokročilost onemocnění v okamžiku } \\
\text { stanovení diagnózy } \\
\text { - vyššír riziko selhání léčby než u AlH-1, relapsy při vysazení léčby velmi časté, proto vyžaduje } \\
\text { většinou dlouhodobou udržovací léčbu }\end{array}$ \\
\hline AlH-3 & - Pozitivní SLA & $\begin{array}{l}\text { - výskyt do } 10 \% \text { prípadů AlH } \\
\text { - klinicky podobná AlH-1 } \\
\text { - většina (všechny prípady?) si vyžaduji doživotní imunosupresivní léčbu }\end{array}$ \\
\hline
\end{tabular}


- V roce 2008 byl publikován zjednodušený skórovací systém AlH (66). Systém hodnotí 4 klinické parametry v celkem 9 stupních.

Původní kompletní systém z roku 1999 má vyšší senzitivitu pro AlH (100\% vs. 95 \%), zatímco zjednodušený systém má vyšší specificitu (90\% vs. $73 \%$ ) (67). Zjednodušený systém nehodnotí efekt imunosupresivní léčby, čímž lze vysvětlit jeho nižší sensitivitu ve srovnání s původním kompletním systémem. Ze srovnání obou systémů také vyplynulo, že původní kompletní systém klasifikuje tzv. kryptogenní hepatitidu jako autoimunitní mnohem častěji než systém zjednodušený (95\% vs. 24\%), zjednodušený systém zase naopak častěji vylučuje AlH u pacientů, kteří mají jiné konkomitantní autoimunitní onemocnění ( $83 \%$ vs. 64\%) (67).

Oba skórovací systémy byly velmi extenzivně evaluovány pomocí retrospektivních analýz mnoha kohort pacientů s diagnózou autoimunitního onemocnění stanovenou ve specializovaných centrech $(67,68)$. Problém všech těchto validací spočívá v tom, že šlo o analýzy retrospektivní, posuzování jednotlivých prípadů nebylo jednotné, nebylo vedeno podle jednotného protokolu. Bohužel dosud nebyla publikována velká, prospektivní, multicentrická studie, která by tyto limitace neměla. Z těchto důvodů je třeba všechny zmíněné skórovací systémy chápat pouze jako pomocný nástroj sloužící dobře pouze v rukou specialisty, který má znalost jejich limitací a v žádném případě systémy nenahrazují expertní úsudek (67). Nelze je použít v prípadech fulminantního průběhu AlH ani u osob po transplantaci jater. Chybou je také jejich použití u osob s primární biliární cholangoitidou.

\section{Klasifikace AlH}

Tradiční klasifikaci a dělení AlH do 3 typů ukazuje tab. 4. Klinický význam tohoto dělení je však nejistý a nemá ani žádnou jednoznačnou terapeutickou implikaci.

\section{Terapie}

Terapie AlH má dle doporučení EASL 2 základní cíle (70):

1. dosáhnout kompletní remise onemocnění, která je definována jako dosažení zcela normální sérové aktivity ALT i AST a normalizace sérové koncentrace lgG.

2. prevenovat progresi jaterního onemocnění v čase (tj. zabránit progresi jaterní fibrózy a rozvoji jaterní cirhózy). Při splnění těchto kritériî $\checkmark$ čase progreduje jaterní fibróza u $<5 \%$ osob.

Kandidáty imunosupresivní léčby jsou všichni pacienti s AlH bez ohledu na klinickou manifestaci onemocnění. Pouze u malé části nemocných, kteří mají dobré jaterní funkce, nemají pokročilou jaterní fibrózu ani cirhózu a mají nízkou histologickou aktivitu (HAl <4), nemusí být imunosupresivní léčba zahájena. U těchto pacientů se však jedná o vysoce individuální rozhodnutí (respektující např. i diskuzi s pacientem), které vyžaduje blízké sledování a monitoraci prípadné progrese onemocnění (14).

Imunosupresivní terapie bývá tradičně dělena na dvě 2 :

1. indukční a

2. udržovací.
Graf 1. Pravděpodobnost udržení remise AlH v čase po vysazení imunosupresivníléčby

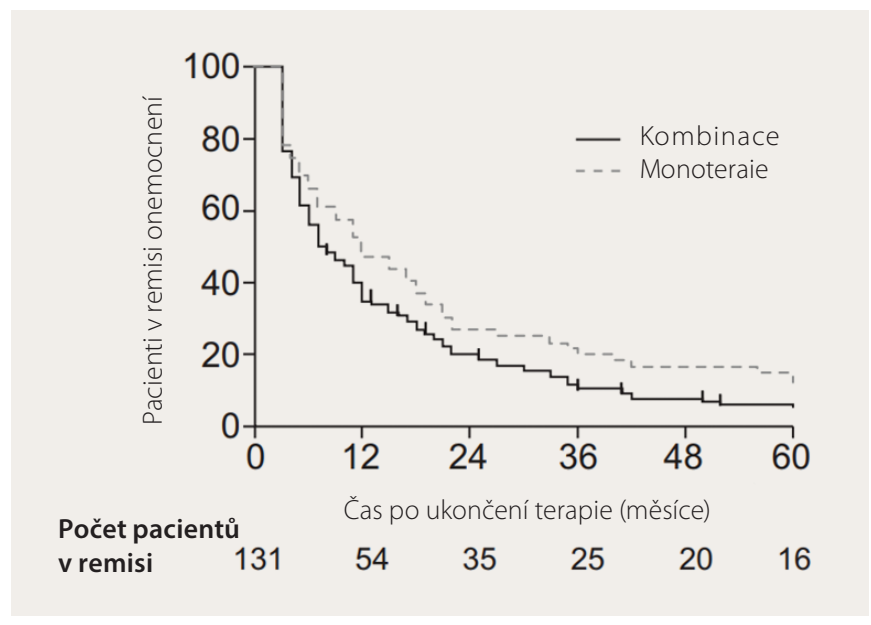

Základem indukční fáze je podání prednisonu v dávce 0,5-1 mg/kg hmotnosti denně s následným postupným snižováním. Pro udržovací fázi je doporučována monoterapie azatioprinem v dávce 1-1,5 mg/kg denně nebo kombinace azatioprinu a malé dávky prednisonu. Tento postup je účinnější než monoterapie prednisonem (69). Standardy Evropské asociace pro studium jater doporučují zahájit léčbu monoterapií prednisonem a azatioprin do léčby doplnit až po 2 týdnech (70). Důvodem je snaha o rozpoznání primární rezistence na léčbu od azatioprinem indukované hepatotoxicity v prípadech přetrvávající elevace ALT/AST. Jako alternativu prednisonu v indukční fázi EASL uvádí podání budesonidu v úvodní dávce 9 mg/den. Doporučení se opírá o randomizovanou studii, která ukázala superioritu kombinace budesonid/azatioprin vůči kombinaci prednisolon/azatioprin ve smyslu dosažení remise i vedlejších účinků (71). Je zajímavé, že podle dotazníkové akce mezi evropskými specialisty tento postup nikdo nepoužívá (72). Budesonid je prínosem spíše v udržovací fázi terapie, kdy je třeba jej upřednostnit zejména u osob netolerujícími prednison pro jeho nežádoucí účinky (73). Bohužel, až 25 \% těchto osob nemá na budesonid dostatečnou odpověd’a je třeba se tedy vrátit u nich k terapii prednisonem. Budesonid je také považován za kontraindikovaný u osob s jaterní cirhózou.

Kombinace prednison + azatioprin v obou fázích je některými autory preferována, protože umožňuje použití nižších dávek prednisonu, čímž omezuje množství kortikodependentních nežádoucích účinků. Oba režimy jsou nicméně stejně účinné ve smyslu dosažení a udržení kompletní remise AlH (74). Monoterapie prednisonem by měla být rezervována pouze pro pacienty s prokázanou nebo očekávanou intolerancí azatioprinu. Nevhodné je také zahajovat léčbu kombinací u pacientů s těžkou akutní manifestací AlH. V těchto prípadech je nevýhodou kombinace skutečnost, že plný účinek azatioprinu nastupuje až za přibližně 6-8 týdnů od zahájení léčby, kdežto prednison má nástup účinku okamžitý. Azatioprin je lék kategorie D podle FDA klasifikace nebezpečnosti jeho použití v graviditě a jako takový ho nelze u gravidních žen doporučit. Nicméně bylo publikováno množství studií gravidních žen léčených azatioprinem pro idiopatické střevní záněty i během gravidity a v těchto nebyly žádné fetální komplikace popsány $(75,76)$. Je však třeba konstatovat, že azatioprin není u AlH lékem esenciálním 
a ve většině prípadů jej Ize nahradit přesně nastavenou vyšší dávkou prednisonu.

Velmi obtížnou otázkou je délka trvání terapie, respektive otázka ukončení imunosupresivní léčby. Je dobře známo, že po ukončení léčby relabuje během 3 let až $80 \%$ osob, přičemž není rozdíl mezi jednotlivými variantami léčby (obr. 1) (77). Jako minimální délka trvání léčby bývá uváděno 24 měsíců léčby od okamžiku dosažení normální biochemické aktivity (70). Biochemická aktivita však nekoreluje s aktivitou histologickou a histologická normalizace se významně opoždujuje za biochemickou (78). Z těchto důvodů mnozí autoři doporučují provést kontrolní jaterní biopsii před ukončením imunosupresivní léčby, a to zejména v prrípadech těžké iniciální aktivity (70). I u pacientů, kteří během 3 let nezrelabují, je však doporučována doživotní monitorace.

Samostatnou skupinou osob, která vyžaduje speciální pozornost, jsou osoby, které výše uvedeným postupem nedosáhnout kompletní remise a osoby, které léčbu první volby netolerují. Problematika léčby této omezené skupiny je velmi speciální, standardní postupy nejsou zdaleka

\section{LITERATURA}

1. Liberal R, Krawitt EL, Vierling JM, et al. Cutting edge issues in autoimmune hepatitis J Autoimmun 2016; 75: 6-19.

2. Leber WJ. Blutproteine und Nahrungseiweiss (Liver, blood pro-teins and nutritive protein). Dtsch Z Verdau Stoffwechselkr 1953; 9: 113-119.

3. Cowling DC, Mackay IR, Taft LI. Lupoid hepatitis. Lancet 1956; 271: 1323-1326.

4. Mackay IR, Weiden S, Hasker J. Autoimmune hepatitis. Ann NY Acad Sci 1965; 124: 767-780 5. Kirk AP, Jain S, Pocock S, et al. Late results of the Royal Free Hospital prospective cont rolled trial of prednisolone therapy in hepatitis $B$ surface antigen negative chronic active hepatitis. Gut 1980; 21: 78-83.

6. Czaja AJ. Autoimmune hepatitis in diverse ethnic populations and geographical regions. Expert Rev Gastroenterol Hepatol 2013; 7: 365-385.

7. Czaja AJ, Bayraktar Y. Non-classical phenotypes of autoimmune hepatitis and advances in diagnosis and treatment. World J Gastroenterol 2009; 15: 2314-2328.

8. Al-Chalabi T, Underhill JA, Portmann BC, et al. Impact of gender on the long-term outcome and survival of patients with autoimmune hepatitis. J Hepatol 2008; 48: 140-147.

9. Manns MP, Czaja AJ, Gorham JD, et al. Diagnosis and management of autoimmune hepatitis. Hepatology 2010; 51: 2193-2213.

10. Stravitz RT, Lefkowitch JH, Fontana RJ, et al. Autoimmune acute liver failure: proposed clinical and histological criteria. Hepatology 2011; 53: 517-526.

11. Fujiwara K, Fukuda Y, Yokosuka O. Precise histological evaluation of liver biopsy specimen is indispensable for diagnosis and treatment of acute-onset autoimmune hepatitis. J Gastroenterol 2008; 43: 951-958.

12. Yasui S, Fujiwara K, Yonemitsu Y, et al. Clinicopathological features of severe and fulminant forms of autoimmune hepatitis. J Gastroenterol 2011; 46: 378-390.

13. Kogan J, Safadi R, Ashur Y, et al. Prognosis of symptomatic versus asymptomatic au toimmune hepatitis: a study of 68 patients. J Clin Gastroenterol 2002; 35: 75-81.

14. Czaja AJ. Features and consequences of untreated type 1 autoimmune hepatitis. Liver Int 2009; 29: 816-823.

15. Czaja AJ, Carpenter HA, Santrach PJ, et al. The nature and prognosis of severe cryptogenic chronic active hepatitis. Gastroenterology 1993; 104: 1755-1761.

16. Heringlake S, Schütte A, Flemming P, et al. Presumed cryptogenic liver disease in Germany: high prevalence of autoantibody-negative autoimmune hepatitis, low prevalence of NASH, no evidence for occult viral etiology. Z Gastroenterol 2009; 47: 417-423.

17. Czaja AJ. Behavior and significance of autoantibodies in type lautoimmune hepatitis. J Hepatol 1999; 30: 394-401.

18. Prasad KK, Debi U, Sinha SK, et al. Hepatobiliary disorders in celiac disease: an update. Int J Hepatol 2011; 2011: 438184.

19. Gassert DJ, Garcia H, Tanaka K, et al. Corticosteroid-responsive cryptogenic chronic hepatitis: evidence for seronegative autoimmune hepatitis. Dig Dis Sci 2007; 52: 2433-2437. 20. Miyake $Y$, Iwasaki Y, Terada R, et al. Clinical features of Japanese type 1 autoimmune hepatitis patients with zone III necrosis. Hepatol Res 2007; 37: 801-805.

21. Kessler WR, Cummings OW, Eckert G, et al. Fulminant hepatic failure as the initial presentation of acute autoimmune hepatitis. Clin Gastroenterol Hepatol 2004 2: 625-631.

22. Czaja AJ, Carpenter HA. Autoimmune hepatitis with incidental histologic features of bile duct injury. Hepatology 2001; 34: 659-665. tak dobře definovány jako léčba v typických případech AlH a přesahuje rozsah a účel tohoto přehledového článku. Je třeba zdůraznit, že svoje místo v terapii těchto obtížných př́padů má i transplantační léčba.

\section{Závĕr}

Autoimunitní hepatitida je príkladem dlouho známého chronického jaterního zánětlivého onemocnění, které, pokud není léčeno, prakticky vždy vede k rozvoji jaterní cirhózy a k významnému zkrácení života. Na druhou stranu je také prvním jaterním onemocněním, u kterého byl právě v parametru dlouhodobého prežití prokázán příznivý efekt farmakologické terapie. Pokud se ohlédneme do minulosti, je potřeba si všimnout, že naše terapeutické možnosti se v posledních 2 desetiletích nijak významně nezměnily. Dưvodem je nepochybně skutečnost, že naše znalosti o patogenezi AlH jsou i ve 21. století velmi omezené a neumožňují dosud širší uplatnění moderních variant cílené léčby. Jedná se ale pravděpodobně o směr, kterým se terapie AlH bude v nejbližším období ubírat.

23. Angulo P, Maor-Kendler Y, Lindor KD. Small-duct primary sclerosing cholangitis: a long-term follow-up study. Hepatology 2002; 35: 1494-1500.

24. Czaja AJ The overlap syndromes of autoimmune hepatitis. Dig Dis Sci 2013; 58: 326-343. 25. Czaja AJ. Cholestatic phenotypes of autoimmune hepatitis. Clin Gastroenterol Hepatol 2014; 12: 1430-1438.

26. Kim WR, Ludwig J, Lindor KD. Variant forms of cholestatic diseases involving small bile ducts in adults. Am J Gastroenterol 2000; 95: 1130-1138.

27. Boberg KM, Chapman RW, Hirschfield GM, et al. Overlap syndromes: the International Autoimmune Hepatitis Group (IAIHG) position statement on a controversial issue. J Hepatol 2011; 54: 374-385.

28. Gatselis NK, Zachou K, Papamichalis P, et al. Comparison of simplified score with the revised original score for the diagnosis of autoimmune hepatitis: a new or a complementary diagnostic score? Dig Liver Dis 2010; 42: 807-812.

29. Homberg JC, Abuaf N, Bernard O, et al. Chronic active hepatitis associated with antiliver/kidney microsome antibody type 1: a second type of "autoimmune" hepatitis. Hepatology 1987; 7: 1333-1339.

30. Gleeson D, Heneghan MA. British Society of Gastroenterology. British Society of Gastroenterology (BSG) guidelines for management of autoimmune hepatitis. Gut 2011; 60: 1611-1629.

31. Czaja AJ, Manns MP. The validity and importance of subtypes in autoimmune hepatitis: a point of view. Am J Gastroenterol 1995; 90: 1206-1211.

32. Muratori P, Lalanne C, Fabbri A, et al. Type 1 and type 2 autoimmune hepatitis in adults share the same clinical phenotype. Aliment Pharmacol Ther 2015; 41: 1281-1287

33. Czaja AJ. Performance parameters of the conventional serological markers for autoimmune hepatitis. Dig Dis Sci 2011; 56: 545-554.

34. Czaja AJ, Nishioka M, Morshed SA, et al. Patterns of nuclear immunofluorescence and reactivities to recombinant nuclear antigens in autoimmune hepatitis. Gastroenterology 1994; 107: 200-207.

35. Gregorio GV, Portmann B, Karani J, et al. Autoimmune hepatitis/sclerosing cholangitis overlap syndrome in childhood: a 16-year prospective study. Hepatology 2001; 33: 544-553. 36. Ma Y, Thomas MG, Okamoto M, et al. Key residues of a major cytochrome P4502D6 epitope are located on the surface of the molecule. J Immunol 2002; 169: 277-285.

37. Czaja AJ. The role of autoantibodies as diagnostic markers of autoimmune hepatitis. Expert Rev Clin Immunol 2006; 2: 33-48.

38. Czaja AJ, Norman GL. Autoantibodies in the diagnosis and management of liver disease. J Clin Gastroenterol 2003; 37: 315-329.

39. Chretien-Leprince P, Ballot E, Andre C, et al. Diagnostic value of anti-F-actin antibodies in a French multicenter study. Ann N Y Acad Sci 2005; 1050: 266-273.

40. Frenzel C, Herkel J, Lüth S, et al. Evaluation of F-actin ELISA for the diagnosis of autoimmune hepatitis. Am J Gastroenterol 2006; 101: 2731-2736.

41. Couto CA, Bittencourt PL, Porta G, et al. Antismooth muscle and antiactin antibodies are indirect markers of histological and biochemical activity of autoimmune hepatitis. Hepatology 2014; 59: 592-600.

42. Martinez-Neira R, dos Remedios CG, Mackay IR. An actin-myosin functional assay for analysis of smooth muscle (anti-microfilament) autoantibodies in human plasma. J Immunol Methods 2008; 338: 63-66. 
43. Soares A, Cunha R, Rodrigues F, et al. Smooth muscle autoantibodies with F-actin specificity. Autoimmun Rev 2009; 8: 713-716.

44. Chan Y, Tong HQ, Beggs AH, et al. Human skeletal musclespecific alpha-actinin-2 and -3 isoforms form homodimers and heterodimers in vitro and in vivo. Biochem Biophys Res Commun 1998; 248: 134-139.

45. Guéguen P, Dalekos G, Nousbaum JB, et al. Double reactivity against actin and alpha-actinin defines a severe form of autoimmune hepatitis type 1. J Clin Immunol 2006 26: 495-505.

46. Ballot E, Homberg JC, Johanet C. Antibodies to soluble liver antigen: an additional marker in type 1 auto-immune hepatitis. J Hepatol 2000; 33: 208-215.

47. Czaja AJ, Donaldson PT, Lohse AW. Antibodies to soluble liver antigen/liver pancreas and HLA risk factors for type 1 autoimmune hepatitis. Am J Gastroenterol 2002; 97: 413-419 48. Czaja AJ, Carpenter HA, Manns MP. Antibodies to soluble liver antigen, P450IID6, and mitochondrial complexes in chronic hepatitis. Gastroenterology 1993; 105: 1522-1528.

49. Efe C, Ozaslan E, Wahlin S, et al. Antibodies to soluble liver antigen in patients with various liver diseases: a multicentre study. Liver Int 2013; 33: 190-196.

50. Volkmann M, Luithle D, Zentgraf $H$, et al. SLA/LP/tRNP((Ser)Sec) antigen in autoimmune hepatitis: identification of the native protein in human hepatic cell extract. J Autoimmun 2010; 34: 59-65.

51. Wies I, Brunner S, Henninger J, et al. Identification of target antigen for SLA/LP autoantibodies in autoimmune hepatitis. Lancet 2000; 355: 1510-1515.

52. Terjung B, Söhne J, Lechtenberg B, et al. p-ANCAs in autoimmune liver disorders recognise human beta-tubulin isotype 5 and cross-react with microbial protein FtsZ. Gut 2010; 59: 808-816.

53. Terjung B, Spengler U, Sauerbruch T, et al. "Atypical p-ANCA" in IBD and hepatobiliary disorders react with a 50-kilodalton nuclear envelope protein of neutrophils and myeloid cell lines. Gastroenterology 2000; 119: 310-322.

54. Roozendaal C, de Jong MA, van den Berg AP, et al. Clinical significance of anti-neutrophi cytoplasmic antibodies (ANCA) in autoimmune liver diseases. J Hepatol 2000; 32: 734-741. 55. Czaja AJ, Pfeifer KD, Decker RH et al. Frequency and significance of antibodies to asialoglycoprotein receptor in type 1 autoimmune hepatitis. Dig Dis Sci 1996; 41: 1733-1740 56. Yoshioka M, Mizuno M, Morisue Y, et al. Anti-asialoglycoprotein receptor autoantibodies, detected by a capture-immunoassay, are associated with autoimmune liver diseases. Acta Med Okayama 2002; 56: 99-105.

57. Johnson PJ, McFarlane IG, McFarlane BM, et al. Autoimmune features in patients with idiopathic chronic active hepatitis who are seronegative for conventional auto-antibodies. J Gastroenterol Hepatol 1990; 5: 244-251.

58. McFarlane IG, Hegarty JE, McSorley CG, et al. Antibodies to liver-specific protein pre dict outcome of treatment withdrawal in autoimmune chronic active hepatitis. Lancet 1984; 2: 954-956

59. Roggenbuck D, Mytilinaiou MG, Lapin SV, et al. Asialoglycoprotein receptor (ASGPR): a peculiar target of liverspecific autoimmunity. Auto Immun Highlights 2012; 3: 119-125.

60. Martini E, Abuaf N, Cavalli F, et al. Antibody to liver cytosol (anti-LC1) in patients with autoimmune chronic active hepatitis type 2. Hepatology. 1988; 8: 1662-1666.
61. Abuaf N, Johanet C, Chretien P, et al. Characterization of the liver cytosol antigen type 1 reacting with autoantibodies in chronic active hepatitis. Hepatology 1992; 16: 892-898.

62. Czaja AJ, Shums Z, Norman GL. Nonstandard antibodies as prognostic markers in autoimmune hepatitis. Autoimmunity 2004; 37: 195-201.

63. Renous R, Lapierre P, Djilali-Saiah I, et al. Characterization of the antigenicity of the formiminotransferasecyclodeaminase in type 2 autoimmune hepatitis. Exp Cell Res 2004; 292: 332-341.

64. Béland K, Lapierre P, Marceau G, et al. Anti-LC1 autoantibodies in patients with chronic hepatitis C virus infection. J Autoimmun 2004; 22: 159-166.

65. Alvarez F, Berg PA, Bianchi FB, et al. International Autoimmune Hepatitis Group Report: review of criteria for diagnosis of autoimmune hepatitis. J Hepatol 1999; 31: 929-938. 66. Hennes EM, Zeniya M, Czaja AJ, et al. Simplified criteria for the diagnosis of autoimmune hepatitis. Hepatology 2008; 48: 169-176.

67. Czaja AJ. Performance parameters of the diagnostic scoring systems for autoimmune hepatitis. Hepatology 2008; 48: 1540-1548.

68. Czaja AJ. Comparability of probable and definite autoimmune hepatitis by international diagnostic scoring criteria. Gastroenterology 2011; 140: 1472-1480.

69. Lamers MMH, van Oijen MGH, Pronk M, et al. Treatment options for autoimmune hepatitis: a systematic review of randomized controlled trials. J Hepatol 2010; 53: 191-198.

70. EASL Clinical Practice Guidelines: autoimmune hepatitis. J Hepatol 2015; 63: 971-1004. 71. Manns MP, Woynarowski M, Kreisel W, et al. Budesonide inducesremission more effectively than prednisone in a controlledtrial of patients with autoimmune hepatitis. Gastroenterology 2010; 139: 1198-1206.

72. Liberal R, de Boer YS, Andrade RJ, et al. Expert clinical man-agement of autoimmune hepatitis in the real world. Aliment Pharmacol Ther 2017; 45: 723-732.

73. Peiseler M, Liebscher T, Sebode M, et al. Efficacy and Limitations of Budesonide as a Second-Line Treatment for Patients With Autoimmune Hepatitis. Clin Gastroenterol Hepatol 2018; 16: 260-267.

74. Sandborn WJ. A review of immune modifier therapy for inflammatory bowel disease: azathioprine, 6-mercaptopurine, cyclosporine, and methotrexate. Am J Gastroenterol 1996; 91: 423-433.

75. Akbari M, Shah S, Velayos FS, et al. Systematic review and meta-analysis on the effects of thiopurines on birth outcomes from female and male patients with inflammatory bowel disease. Inflamm Bowel Dis 2013; 19: 15-22.

76. Casanova MJ, Chaparro M, Domènech E, et al. Safety of thiopurines and anti-TNF-alpha drugs during pregnancy in patients with inflammatory bowel disease. Am J Gastroenterol 2013; 108: 433-440

77. van Gerven NMF, Verwer BJ, Witte BI, et al. Relapse is almost universal after withdrawal of immunosuppressive medication in patients with autoimmune hepatitis in remission. J Hepatol 2013; 58: 141-147.

78. Soloway RD, Summerskill WH, Baggenstoss AH, et al. Clinical, biochemical, and histological remission of severe chronic active liver disease: a controlled study of treatments and early prognosis. Gastroenterology 1972; 63: 820-833. 